\title{
Supermercados, estrategias y pequeños productores hortícolas en el municipio de Acatzingo: el caso Walmart
}

\section{Supermarkets, strategies and small horticultural farmers in the municipality of Acatzingo: the Walmart case}

Diosey Ramón Lugo-Morin*

\begin{abstract}
In order to learn the strategies of commercialization of Walmart store and the opportunities of development for the small horticultural farmers before this supermarket chain, a study was realized in one of the main horticultural municipalities of the state of Puebla, Mexico. We conclude that direct negotiations of Walmart with small horticultural farmers, the suppression of a link of the chain of value of the horticultural system and the manipulation of the prices of the vegetables are all strategies that aim at the hegemony of this supermarket chain in the horticultural system.
\end{abstract}

Keywords: supermarkets, rural development, Mexico, competitiveness, modern retail

\section{Resumen}

Con el objetivo de conocer las estrategias de comercialización de Walmart y las oportunidades de desarrollo de los pequeńos productores hortícolas, se realizó un estudio en Acatzingo, uno de los principales municipios hortícolas del estado de Puebla, México. Se concluye que las negociaciones directas que establece Walmart con los pequeños productores hortícolas, la supresión de un eslabón de la cadena de valor del sistema hortícola y la manipulación de los precios de las hortalizas, son estrategias que apuntan hacia la hegemonía de esta cadena de autoservicio en el sistema hortícola.

Palabras clave: supermercados, desarrollo rural, México, competitividad, venta al detalle. 


\section{Introducción}

América Latina en la actualidad experimenta un acelerado crecimiento de los supermercados, entre las causas de este fenómeno destacan: el aumento del patrón demográfico, las transformaciones en los territorios rurales que han originado un despliegue de estrategias (pluriactividad, multiracionalidad, etnocompetitividad, emergencia de procesos relacionales y el establecimiento de redes sociales) entre los pequeños productores; en particular, aquellos pertenecientes al sector hortícola, así como una tendencia en las políticas agrícolas de la región.

De acuerdo con Reardon y Berdegué (2002) los supermercados, junto con los procesadores de alimentos a gran escala, han transformado profundamente los mercados agroalimentarios de la región. Muchos de estos cambios suponen grandes desafíos (incluso la exclusión) de pequeños agricultores y empresas pequeñas de procesamiento y distribución, pero también encierran un potencial de grandes oportunidades.

México no escapa a esta realidad: el dinamismo y desarrollo histórico de los supermercados en el país está asociado con el aumento de la población, con los cambios en los patrones de consumo, en particular en las zonas metropolitanas, así como con la instrumentación de políticas agrícolas que favorecen el establecimiento y sistemas de arreglos de los supermercados.

El crecimiento de los supermercados ha originado cambios en las estrategias de comercialización donde la intermediación era una figura importante en sus transacciones, sin embargo, en la actualidad la dinámica económica impacta en los ingresos de los hogares mexicanos, provocando un descenso en los volúmenes de ventas, situación que obliga a los supermercados a conquistar espacios perdidos. El caso de Walmart es relevante debido a que una de sus estrategias de comercialización es "un mayor acercamiento a los pequeños productores hortícolas" ya que los productos perecederos son de importancia en términos de ingresos económicos. Por ejemplo, Schwentesius y Gómez (2006) reportan ingresos de $12 \%$ sobre el total de las ventas en el caso de Walmart.

El viraje estratégico hacia los pequeños productores, es catalogado como positivo para estos actores ya que representa mejoras en los ingresos económicos, pero aún existen fuertes barreras que les impiden a los pequeños productores acceder a este mercado, algunas de estas barreras se enmarcan en el sistema de arreglos (entrega continua en calidad y volumen, exigencias de empaque y refrigeración; pagos diferidos y trasportación y hora de entrega) que establecen las tiendas de autoservicio. Situación que exige a los pequeños productores cambios tecnológicos y organizacionales que en la mayoría de los casos requieren de un fuerte financiamiento. 
En este contexto, la presente investigación tiene como objetivo examinar las estrategias de comercialización de Walmart y su impacto en los pequeños productores hortícolas del municipio de Acatzingo.

\section{Consideraciones metodológicas}

La investigación se realizó en Acatzingo, municipio posicionado en un enclave de importancia estratégica por ser una de las zonas productoras de hortalizas más importante de Puebla. Se ubica al centro del estado de Puebla (mapa I) a una altura de $2160 \mathrm{msnm}$, entre las coordenadas: $18^{\circ}$ 58’ Norte y 970 46' Oeste; el clima se clasifica según Holdridge (1978) como (A) C w”) (w) b (i')g templado subhúmedo con lluvias en verano; temperatura media anual $19.5^{\circ} \mathrm{C}$ y precipitación media $788.3 \mathrm{~mm}$. Tiene una extensión territorial de 12,500 hectáreas, de las cuales $70.6 \%$ es superficie agrícola aprovechable. La población económicamente activa del sector primario es de 4.901 (Rappo y Vázquez, 2006). De las cifras reportadas se desprende que existen unas 250 unidades de producción rural (UPR) que se dedican a la producción de hortalizas (Lugo-Morin, 2010a).

Para cumplir con el objetivo planteado se abordó el componente de comercialización del sistema productivo hortícola de Acatzingo y sus actores sociales con particular énfasis en los pequeños productores. El sistema productivo no cuenta con financiamiento y está integrado por tres componentes: el proceso productivo agrícola, los bienes y servicios para la producción y la comercialización.

Se realizó trabajo de campo en los meses de julio de 2008 a octubre de 2009, bajo un enfoque cualitativo. Se aplicaron siete entrevistas semiestructuradas a actores vinculados con el componente comercialización del sistema productivo hortícola del municipio y se realizó observación participante.

La muestra fue seleccionada por procedimientos no probabilísticos, utilizándose el muestreo bola de nieve, en el que los individuos seleccionados inicialmente fungieron como informadores para identificar a otras personas con las características deseadas (Snijders, 1992; Santesmases, 2001; Browne, 2005).

Las entrevistas se orientaron a identificar las relaciones comerciales y apropiación de la renta que genera el sistema hortícola, con la idea de captar la lógica racional del pequeño productor en la dinámica del componente de comercialización. La observación participante captó de manera particular las estrategias que han desplegado los pequeños productores, en sus unidades de producción, en respuesta a las interacciones con los actores vinculados al componente de comercialización. La siner- 


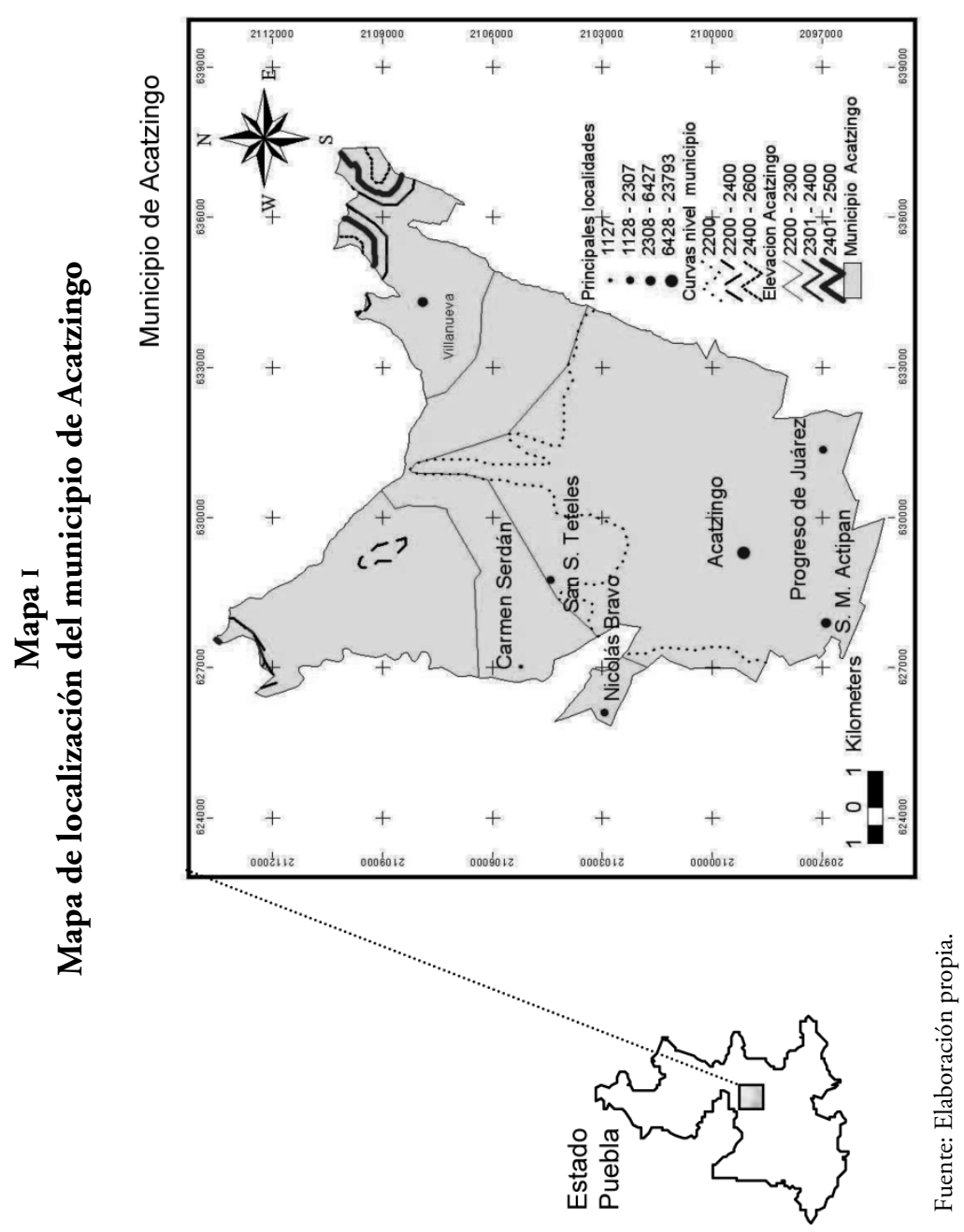


gia de ambas técnicas permitió valorar el sistema de arreglos que establecen los pequeños productores hortícolas con Walmart, entre otros.

De acuerdo con Lugo-Morin et al. (2010b) en este componente (comercialización) se identifican dos tipos de capital: el comercial, el cual permite soportar las transacciones de compra-venta de productos sin realizar inversión con intermediarios locales, y el empresarial, que no sólo soporta las operaciones de compra-venta de productos sino también se emplea para realizar inversiones tales como infraestructura, tecnología y transporte con empacadoras y exportadoras, así como cadenas de comercio: a) Intermediarios locales: operan con capital comercial, es un sector que vive en la región y conoce el sistema productivo, especialmente de los agricultores, lo que les permite establecer acuerdos para la comercialización. Poseen recursos económicos para transacciones diarias, son dueños de medios de transportes y pueden o no poseer tierras. Estos actores, debido al conocimiento del ámbito regional y su experiencia, ubican a los pequeños productores en sus predios, estableciendo arreglos de compras inmediatas, negociando el precio. Este sector por lo general no realiza inversiones productivas; b) Empresas empacadoras y exportadoras: este sector posee un alto capital económico e infraestructura. Se localizan geográficamente donde se ubican los grandes centros de producción hortícola. Se vinculan a la producción a través de agricultores que tienen un liderazgo regional para establecer compromisos de compraventa. Algunas empresas para posicionarse en el mercado regional rentan bodegas en los municipios con mayor producción hortícola. Demandan hortalizas de excelente calidad ofreciendo buenos precios, y c) Empresas comerciales: conocidas como tiendas de autoservicio, cadenas de comercio o comercializadoras, poseen capital e infraestructura y pueden o no pertenecer a la región de la cual se proveen. Sus representantes más importantes son: Walmart, Soriana y Chedraui. Schwentesius y Gómez (2006) en su estudio caracterizan ampliamente a este sector y lo califican como un componente de importancia en el marco del sistema agroalimentario de México.

\section{Las zonas hortícolas de México y su evolución}

El desarrollo hortícola en México mostró por muchos años un carácter anticíclico frente a las fuertes tendencias de contracción observadas en otros productos. Mientras los granos están en una situación de crisis desde los años sesenta y los cárnicos desde mediados de los años ochenta, las hortalizas han podido mantener una dirección hacia el crecimiento. En parte, este comportamiento se explica por la reorientación del consumo familiar de carnes a hortalizas, manteniéndose el dinamismo del 
mercado hortícola como respuesta a la contracción de la demanda de otros alimentos (Schwentesius y Gómez, 1997; Borbón, 2001).

En México, de acuerdo con Lugo-Morin (2010a) se identifican cuatro grandes regiones de producción de hortalizas diferenciadas por su nivel de tecnificación, organización y distribución: a) la región noreste es altamente tecnificada con una producción selectiva (jitomate, berenjena, chile, cebolla) caracterizada por medianos y grandes productores, algunos estados representativos son: Chihuahua, Coahuila, Nuevo León; b) la región del bajio-pacifico tiene un buen nivel de tecnificación; con una producción también selectiva, basada en lechugas, brócoli, coliflor, zanahorias. Al igual que la primera región se caracteriza por la presencia de medianos y grandes productores, algunos estados representativos son: Baja California, Jalisco, Michoacán, Guanajuato, San Luis Potosí; c) la región centro cuenta con un nivel de tecnificación baja a mediana, su producción hortícola es altamente diversificada se caracteriza por la presencia de pequeños productores. El sistema hortícola local destina la producción a los mercados local, regional y nacional con cierto grado de consolidación. Por otra parte, las capacidades productivas con distintos niveles tecnológicos posibilita su inserción en el mercado internacional, algunos estados representativos son Tlaxcala, Puebla, México, Veracruz, Morelos, y d) la región sureste con un nivel de tecnificación nulo a bajo, su producción hortícola es poco diversificada, se caracteriza por la presencia de pequeños productores. El sistema hortícola local destina la producción al mercado local. Algunos estados representativos son Veracruz, Chiapas, Tabasco, Yucatán y Quintana Roo.

Las cuatro regiones tienen en común que están asociadas a paisajes de valle, lo que ha posibilitado condiciones agroecológicas idóneas para la producción hortícola, otro aspecto es la proximidad geográfica que tienen las distintas regiones con una diversidad de mercados. En este sentido, a las dos primeras regiones debido a las condiciones agroecológicas, la posición geográfica privilegiada y la contratación de mano de obra barata, les ha permitido obtener ventajas competitivas logrando posicionarse en el mercado internacional.

De la región centro, el estado de Puebla es parte de los circuitos que abastecen el mercado nacional e internacional. Dependiendo del tamańo de la parcela y las condiciones para la producción se identifican productores hortícolas con un acceso diferenciado a los medios de producción. Una parte de las hortalizas que se producen en el estado se comercializan en la central de abasto de San Salvador de Huixcolotla, la cual, por una parte, abastece a otras regiones como ciudad de México, Quintana Roo, Veracruz y Yucatán aspecto que resalta su importancia a nivel nacional. Por otro lado, es parte fundamental de los circuitos que abastecen a las 
grandes cadenas de supermercados, en particular Walmart. En el contexto de la región, Lugo-Morin (2010a) advierte que en el año 2009 las hortalizas aportaron a los agricultores más de 450 millones de dólares.

El análisis previo muestra la relevancia que tiene la región en la producción hortícola. De acuerdo con Rappo y Vázquez (2006) la región, la integran 13 municipios: San Francisco Mixtla, San Isabel Tlalnepantla, Cuautinchán, Tzicatlacoyan, Tecali de Herrera, Los Reyes de Juárez, San Salvador de Huixcolotla, Tepeaca, Cuapiaxtla de Madero, Tecamachalco, Santo Tomás Hueyotlipan, Tochtepec y Acatzingo. Este último por sus particularidades: dinamismo territorial y diversidad en la producción hortícola, posibilita una buena representación de la región (cuadro 1).

\section{Los pequeños productores hortícolas de Acatzingo}

Los resultados muestran que el pequeño productor de Acatzingo tiene una edad que oscila entre los 26 y 65 años, con un promedio de 3.5 hectáreas por unidad productiva, la cual se caracteriza por la propiedad de la tierra y el conocimiento local y los recursos económicos; lo que les permite cierta autonomía referente a qué, cuándo, cómo y cuánto producir y determinar la fuerza laboral requerida, misma que emplean de manera combinada, es decir, $85 \%$ es mano de obra familiar y $75 \%$ es contratada.

Los cultivos que tienen presencia en el municipio de Acatzingo son: acelga (Beta vulgaris var. Cicla), betabel (Beta vulgaris), brócoli (Brassica oleracea), calabacita (Cucurbita pepo), cebolla cambray (Allium cepa), cebollín (Allium schoenoprasum), cilantro (Coriandrum sativus), col (Brassica oleracea), coliflor (Brassica oleracea), ejote (fruto inmaduro de Phaseolus vulgaris), espinaca (Spinacea oleracea), huauzontle (Chenopodium nuttalliae), lechuga (Lactuca sativa), pepino (Cucumis sativus), poro (Allium ampeloprasum), rábano (Raphanus sativus), jitomate (Solanum lycopersicum), tomate verde (Physalis ixocarpa) y zanahoria (Daucus carota). Del listado presentado la muestra de los pequeños productores hortícolas entrevistados prefieren sembrar cebollín, cilantro, coliflor, brócoli y zanahoria, y en menor medida, acelga, ejote, poro, lechuga y rábano. Estas preferencias se han construido debido a la demanda del mercado, principalmente, las tiendas de autoservicio (cuadro 2). 


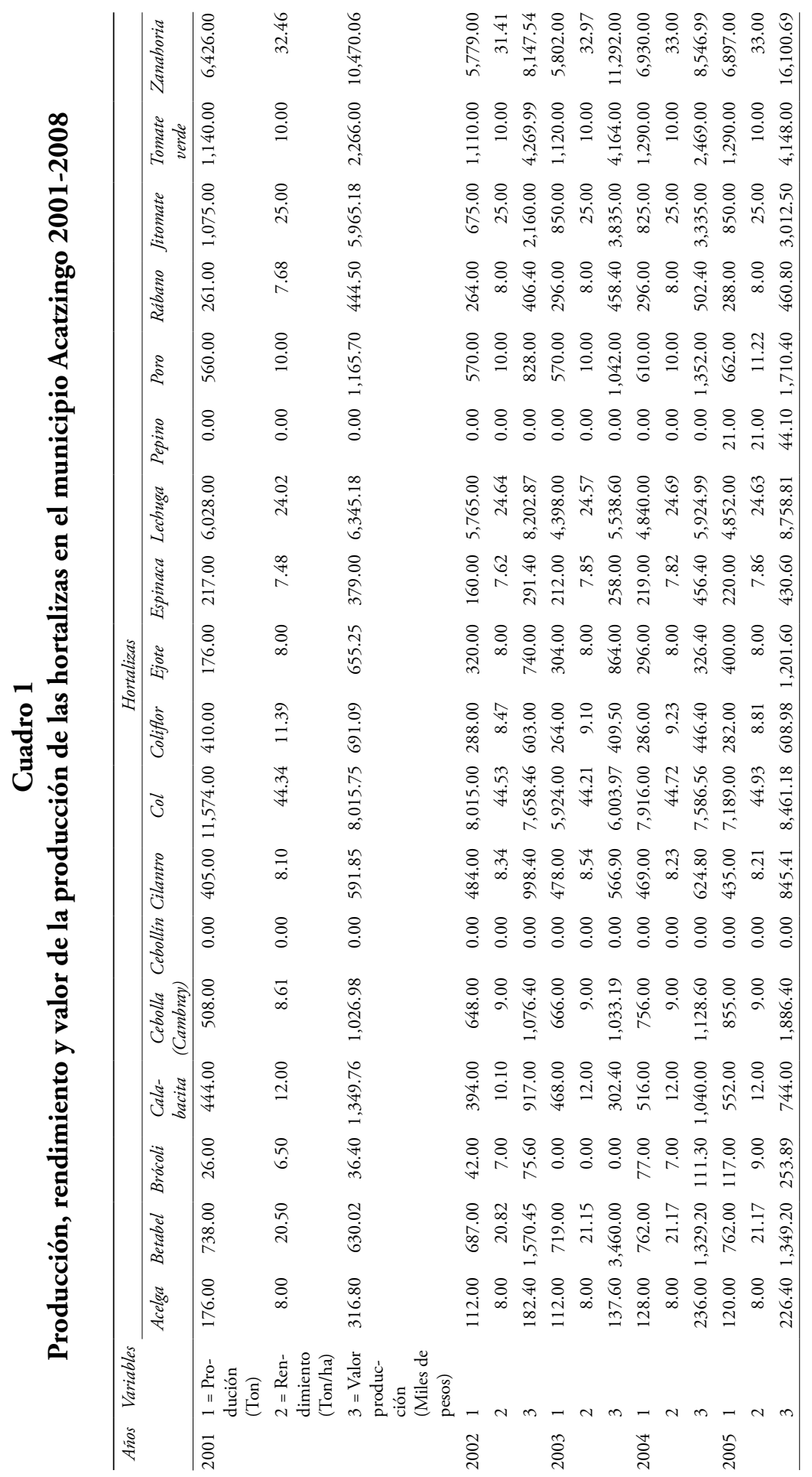




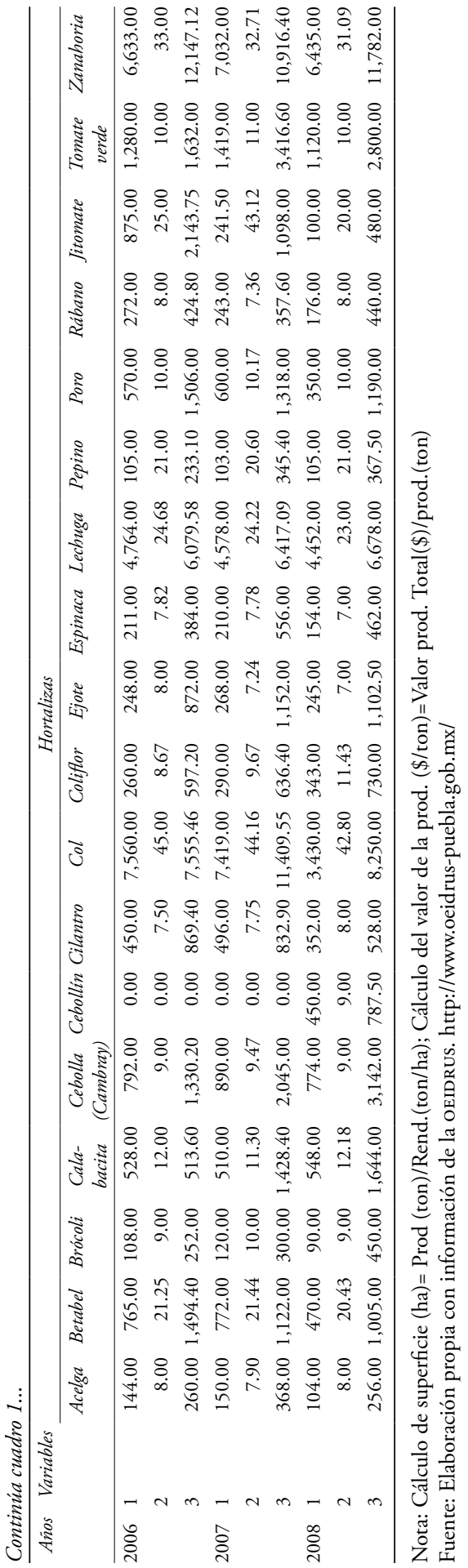




\section{Cuadro 2}

Principales rubros hortícolas de venta directa a Walmart, 2009

\begin{tabular}{lcc}
\hline Hortaliza & $\begin{array}{c}\text { Volumen de } \\
\text { producción (Ton.) }\end{array}$ & $\begin{array}{c}\text { \% del volumen de producción } \\
\text { destinado a Walmart }\end{array}$ \\
\hline Cebollín & 450 & 40 \\
Brócoli & 90 & 25 \\
Cilantro & 352 & 25 \\
Acelga & 180 & 20 \\
Poro & 600 & 10 \\
Rábano & 176 & 10 \\
Tomate verde & 1120 & 5 \\
\hline
\end{tabular}

Fuente: Elaboración propia con base en los datos recopilados en campo.

Este pequeño productor es la base del sistema productivo hortícola. Las relaciones que establece con los actores sociales del componente de comercialización, en particular, con las tiendas de autoservicio son de negociación y subordinación. El siguiente análisis realizado a 11 de los cultivos que tienen presencia en el municipio, con base en las entrevistas y la observación participante, evidencia lo señalado.

Acelga (Beta vulgaris var. Cicla). Pertenece a la familia Quenopodiaceae, es una planta bianual cuya parte comestible la constituyen las hojas (fotografía I). Es una hortaliza de clima frío pero tolera tanto heladas como temperaturas altas, en México se puede explotar todo el año. La temperatura requerida para su germinación es de 10 a $25^{\circ} \mathrm{C}$.

\section{Fotografía I}

Variedades de acelga presente en Acatzingo

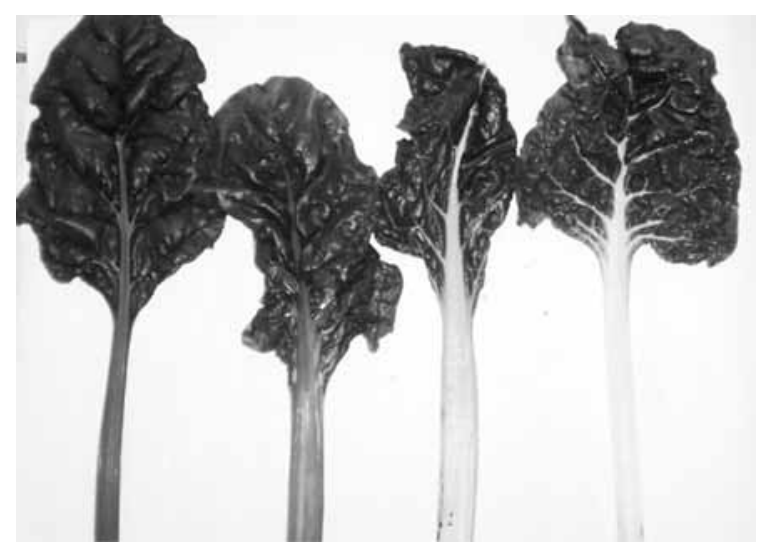


Es un cultivo que en los últimos años, a nivel municipal, ha mantenido una superficie de siembra de 15 hectáreas con una producción que oscila entre las 100 y 180 toneladas (oeIdrus, 2009). En Acatzingo, se acostumbra a sembrarlo en cuartos de hectáreas debido a que no tiene una diversidad de compradores y es el mismo productor quien se encarga de cosecharla y comercializarla directamente. Este último aspecto reduce su costo de producción debido a las cualidades del cultivo (rebrote), es decir, dependiendo del tratamiento posterior al primer corte que se da a los 65 días, se pueden hacer posteriores cortes cada 15 días hasta seis veces, esto posibilita que el pequeño productor de acelga pueda incrementar sus ganancias.

Los costos de producción de la acelga por hectárea están por debajo de los 20,000 pesos en el municipio. Si consideramos que el rendimiento de la acelga es ocho toneladas por hectárea, se comercializa en manojos de dos kilogramos, es decir que una hectárea produce en promedio 4,000 manojos a dos pesos cada uno.

Para este cultivo se presentan dos tipos de comercialización: la venta directa en la central de abasto de Huixcolotla y la venta a empresas comerciales o tiendas de autoservicio. En el primer caso, comercializan entre 70 y $80 \%$ de su producción con una frecuencia semanal, allí concurren compradores de ciudad de México y Puebla, el pequeño productor de acelga hace arreglos con dichos compradores que generalmente les son favorables al permitirles ingresos netos por el orden de $20 \%$ (figura I). En el segundo, comercializan entre 30 y $20 \%$ de su producción con las empresas comerciales: Walmart y Soriana, aunque las negociaciones les son favorables, el pago es diferido y se establece de la siguiente forma: se firma un contrato con una semana de anterioridad donde se pacta el precio y se exponen las especificaciones, normas y calidades, a los 30 días se hace el pago a través de cuentas electrónicas.

\section{Figura I}

\section{Distribución porcentual de la cadena de valor de la acelga}

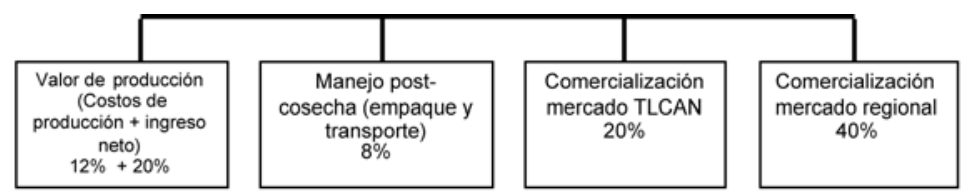

Fuente: Elaboración propia con base en los datos recopilados en campo.

Esta estrategia de comercialización de los pequeños productores de acelga es efectiva debido a que, en el primer caso, les permite capitalizarse, este aspecto le da margen de maniobra para que en el segundo caso 
puedan establecer arreglos con pagos diferidos a 30 días donde negociarían márgenes de ingresos que, según ellos, son buenos.

Apio (Apium graveolens). Pertenece a la familia Umbelliferae, es una planta bianual cuya parte comestible la constituyen básicamente los tallos. Hortaliza propia de climas templados y frescos, se desarrolla bien en cualquier tipo de suelo, prefiriendo los franco-arenosos, cuenta con buen contenido de materia orgánica; se clasifica como ligeramente tolerante a la acidez.

Ha sido un cultivo de importancia en el municipio debido a su demanda constante en pequeñas cantidades, razón por la cual la superficie de siembra se mantiene entre 8 y10 hectáreas. Adicionalmente, los costos de producción del apio pueden, en ocasiones, ser relativamente elevados debido al alto costo de los agroquímicos. En Acatzingo se trabaja por cuartos de hectáreas o la hectárea completa pero escalonada, esta organización de la producción ha originado que el cultivo no tenga presencia en las estadísticas regionales. Los costos de producción del apio por hectárea están por los 60,000 pesos, tiene un rendimiento promedio de 20 toneladas por hectárea, su cosecha se puede manejar por pieza o manojo que puede tener entre dos y tres kilogramos. Su precio varía según la oferta y la demanda, en promedio un kilogramo puede costar cinco pesos.

Para este cultivo se presentan dos tipos de comercialización: la venta al mercado internacional y la venta al mercado nacional. En el primer caso, cuando hay demanda que coincide con los meses de invierno en Estados Unidos (época en que se ve afectada la producción de California, principal estado productor de Apio), se comercializan entre 70 y $80 \%$ de su producción; el pequeño productor negocia con las empresas empacadoras, pudiendo obtener un precio que supera los seis pesos por kilogramo. El destino de la producción es el mercado de Estados Unidos y el resto se destina al mercado del sureste. En el segundo caso, cuando no hay demanda del mercado internacional, se comercializa $100 \%$ de su producción en la central de abasto de Huixcolotla con destino al mercado del sureste. El pequeño productor negocia con los compradores que concurren a la central de abasto y establece arreglos que le permiten ingresos netos por encima de los costos de producción en 10\% (figura II).

\section{Figura II}

\section{Distribución porcentual de la cadena de valor del apio}

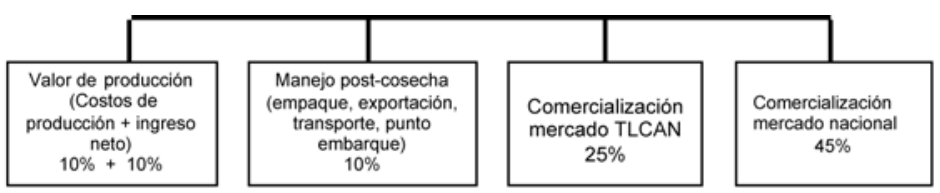

Fuente: Elaboración propia con base en los datos recopilados en campo. 


\section{Fotografía II El cultivo de brócoli}

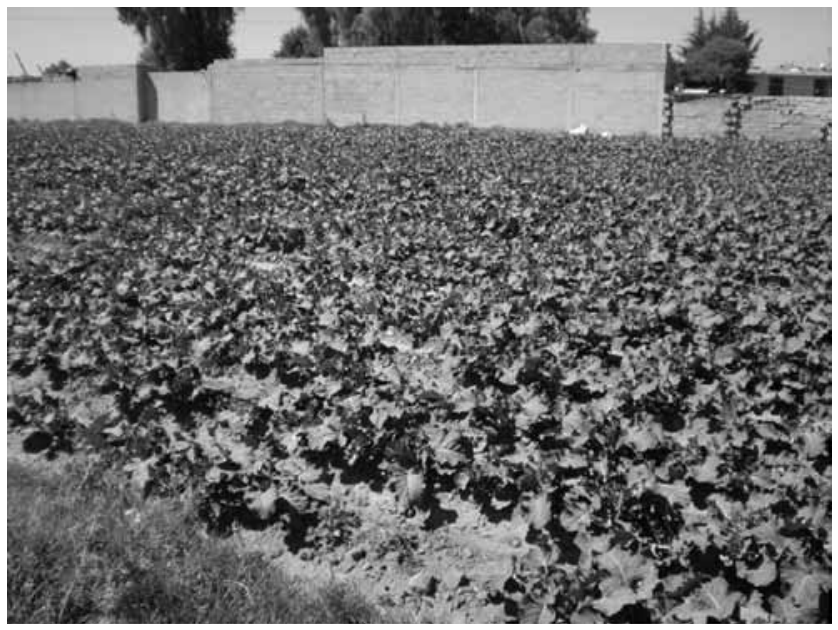

Se constata que el pequeño productor de apio construye su estrategia de comercialización a partir de una demanda constante del mercado del sureste, lo que le permiten capitalizarse, asimismo posibilita mantener su producción aun si en el siguiente ciclo productivo obtiene márgenes de ingresos negativos. Por otra parte, existe un potencial mercado internacional de carácter estacional que puede ser aprovechado por los pequeños productores del municipio, esto sustentaría un aumento progresivo del cultivo sin descuidar el criterio de calidad. En este mercado, el consumidor estadounidense toma en consideración varios factores que inciden en su decisión de compra de productos frescos, el principal es el sabor del producto, así como su apariencia general y la limpieza del producto, también influye el grado de maduración y su valor nutricional (FIU, 2006).

Brócoli (Brassica oleracea L.). Pertenece a la familia Brassicaceae, antiguamente Cruciferae (fotografía II), la planta desarrolla solamente las hojas donde se encuentra la pella (parte que se comercializa). Es un cultivo que tiene buen desarrollo durante las estaciones de otoño e invierno, necesita que la temperatura durante la fase de crecimiento oscile entre 20 y $24^{\circ} \mathrm{C}$; para poder iniciar la fase de inducción floral necesita entre 10 y $15^{\circ} \mathrm{C}$ durante varias horas del día. El brócoli ha sido calificado como la hortaliza de mayor valor nutritivo por unidad de peso de producto comestible.

En la zona, su producción se concentra en los municipios de Los Reyes de Juárez, Tecamachalco y Cuapiaxtla de Madero, para el año 2007, según la Sagarpa (2008), entre los tres municipios se obtuvo un volumen de producción de 3,126 toneladas con un valor de la producción superior 
a los 7,000,000 de pesos. En Acatzingo su producción alcanzó para el 2008, las 90 toneladas con un valor de 450,000 pesos. Tiene un costo de producción promedio de 30,000 pesos por hectárea.

El cultivo en el municipio tiene un rendimiento promedio de 10 toneladas por hectárea, pudiendo al canzar las 15 toneladas, esta variabilidad en el rendimiento está supeditada al buen o mal manejo agronómico del cultivo. Su precio depende de la oferta y la demanda, en temporadas de sobreproducción no supera el peso por kilo, cuando hay demanda puede alcanzar hasta los ocho pesos por kilo. En este sentido, según los pequeños productores, las temporadas buenas se ubican entre septiembre y febrero, meses en los que el consumo es de importancia, posibilitando ingresos netos hasta de $15 \%$ (figura III).

\section{Figura III}

\section{Distribución porcentual de la cadena de valor del brócoli}

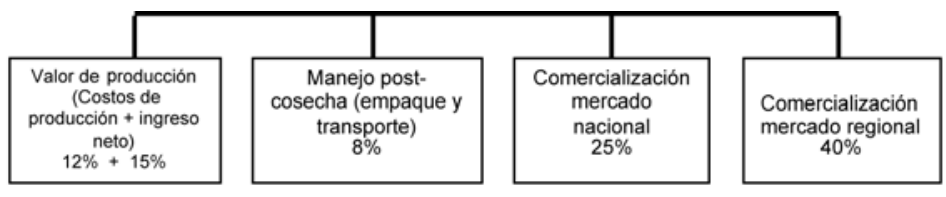

Fuente: Elaboración propia con base en los datos recopilados en campo.

El mercado del brócoli es diversificado, su producción se distribuye de la siguiente manera: $10 \%$ se vende por huerta, $25 \%$ se comercializa en la central de abasto de Huixcolotla, otro $25 \%$ tiene como destino el sureste mexicano y $40 \%$ está destinado a las tiendas de autoservicio, en particular Walmart (25\%) y Soriana (15\%).

En el caso del brócoli los pequeños productores establecen con los compradores relaciones de negociación y subordinación. En la central de abasto de Huixcolotla, debido a la competencia los productores, en ocasiones establecen relaciones de conflicto originadas por la conformación del precio final.

Cebollín (Allium schoenoprasum). Pertenece a la familia Liliaceae, es una planta que posee un sistema de rizomas y tubérculos, de donde emergen brotes erectos de hasta $30 \mathrm{~cm}$ de altura; el brote de los tubérculos tiene lugar a temperaturas entre 10 y $45^{\circ} \mathrm{C}$, las óptimas se encuentran entre 30 y $35^{\circ} \mathrm{C}$. Usualmente un tubérculo sólo da uno o dos rizomas, que se desarrollan próximos a la superficie del suelo. Se siembra en forma directa con un distanciamiento entre 20 y $25 \mathrm{~cm}$ entre surco. Después de la siembra se coloca una capa liviana de abono orgánico y se riega. Las semillas germinan a los siete días, dejando una población de 70 plantas 
por metro lineal. La cosecha se inicia a los 75 días de sembrado, o cuando los tallos alcancen un diámetro de un centímetro.

El cultivo, en el municipio, tiene un rendimiento de 10 toneladas por hectárea. Su precio depende de la oferta y la demanda, y varía según el destino del producto: su venta en la central de abasto de Huixcolotla alcanza los tres pesos por kilo, para el mercado de México se ubica en cinco pesos por kilo y para las tiendas de autoservicio en siete pesos por kilo. El cebollín se comercializa por manojo que equivale a seis kilos.

Los pequeños productores de cebollín señalan que su demanda es constante durante todo el año con una ligera tendencia a la alza de octubre a diciembre. Aunque los productores no señalaron a detalle sus costos de producción, indicaron que obtienen ganancias netas de 5,000 pesos por hectárea (figura Iv). Cuando las ventas tienen como destino el mercado de exportación o las tiendas de autoservicio pueden aumentar hasta 4,000 pesos por hectárea.

\section{Figura IV}

\section{Distribución porcentual de la cadena de valor del cebollín}

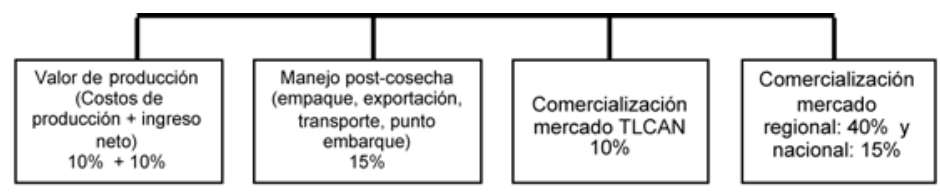

Fuente: Elaboración propia con base en los datos recopilados en campo.

El mercado del cebollín le permite al pequeño productor establecer relaciones de negociación y subordinación. Las primeras surgen al considerar que su producción tiene cabida en un mercado diversificado con buenas expectativas debido a las demandas de Estados Unidos y la constante demanda del mercado nacional. La producción se distribuye de la siguiente manera: $15 \%$ se comercializa en la central de abasto de Huixcolotla, $5 \%$ tiene como destino el sureste mexicano, $60 \%$ está destinado a las tiendas de autoservicio, en particular Walmart (40\%), Soriana (20\%) y $15 \%$ al mercado de exportación. Las segundas, surgen de las ventas por huerta donde los pequeños productores no salen favorecidos debido al esquema de arreglos en dos partes que le impone el intermediario local, el porcentaje en esta modalidad de venta se estima en cinco por ciento.

Cilantro (Coriandrum sativus L.). Pertenece a la familia Apiaceae, herbácea de 40 a 60 centímetros de altura, de tallos erectos, lisos y cilíndricos, ramificados en la parte superior. Requiere un clima templado, y aunque puede tolerar un clima templado-cálido también puede experimentar una disminución del rendimiento. Se cultiva en camas elevadas 
de 97 a $102 \mathrm{~cm}$, con dos líneas por cama. La cosecha puede realizarse entre los 40-60 días, que es cuando el cultivo alcanza una altura superior a las cinco pulgadas, y hasta los cuatro meses, para la producción de semilla madura.

El cultivo en el municipio tiene un rendimiento promedio de 20 toneladas por hectárea. Su precio depende de la oferta y la demanda y varía según el destino del producto, su venta en la central de abasto de Huixcolotla puede alcanzar los siete pesos por kilo (manojo placero); para el mercado de México se ubica en 25 pesos por kilo (manojo mexicano) y para el mercado de exportación y las tiendas de autoservicio puede superar los 30 pesos por kilo. Otra modalidad de venta es la huerta que puede costar por hectárea un promedio de 30,000 pesos. El cilantro se comercializa por manojo lo que equivale a cinco kilos.

Los pequeños productores de cilantro señalan que su demanda es constante durante todo el año y uno de los mercados en auge es el estadounidense. Esta posibilidad ha generado que en el municipio de Acatzingo la superficie de siembra se esté incrementando gradualmente. El costo de producción promedio del cultivo es de 35,000 pesos, lo que posibilita obtener ingresos netos por encima de los costos de producción en $15 \%$ (figura v). Pero el margen de ganancia puede ser negativo cuando se realiza la venta por huerta, ya que está por conformarse el precio final del cilantro, pero esta desinformación también puede ser un arma de doble filo para el intermediario local.

\section{Figura $\mathbf{V}$}

\section{Distribución porcentual de la cadena de valor del cilantro}

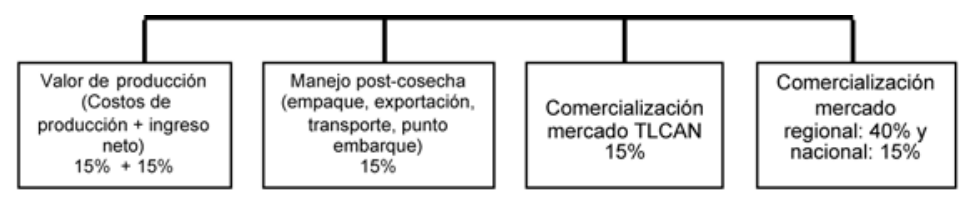

Fuente: Elaboración propia con base en los datos recopilados en campo.

El mercado del cilantro al igual que el del cebollín, le permite al pequeńo productor establecer relaciones de negociación y subordinación. Las primeras surgen al considerar que su producción tiene cabida en un mercado diversificado con buenas expectativas debido a la demanda de Estados Unidos y la constante demanda del mercado nacional. La producción se distribuye de la siguiente manera: $40 \%$ se comercializa en la central de abasto de Huixcolotla, y otro $10 \%$ tiene como destino el mercado de la ciudad de México, y $60 \%$ restante está destinado a las tiendas de autoservicio, en particular Walmart (25\%), Soriana (10\%) y $10 \%$ al 
mercado de exportación. Las segundas surgen de las ventas por huerta donde los pequeños productores no resultan favorecidos debido al esquema de arreglos en dos partes que le impone el intermediario local, el porcentaje en esta modalidad de venta se estima en un cinco por ciento.

Col o repollo (Brassica oleracea L.). Pertenece a la familia Brassicaceae antiguamente Cruciferae, es una planta herbácea, tiene hojas anchas y variadas: ovales, oblongas, circulares, lisas, rizadas, lobuladas en su base (fotografías III-IV). Para su normal desarrollo y producción requieren de temperaturas entre 15 y $20^{\circ} \mathrm{C}$, el suministro de agua debe distribuirse durante todo el ciclo de cultivo; se puede cultivar en gran variedad de suelos, desde arenosos y limo arenosos hasta franco arenosos.

\section{Fotografía III El cultivo de la col}

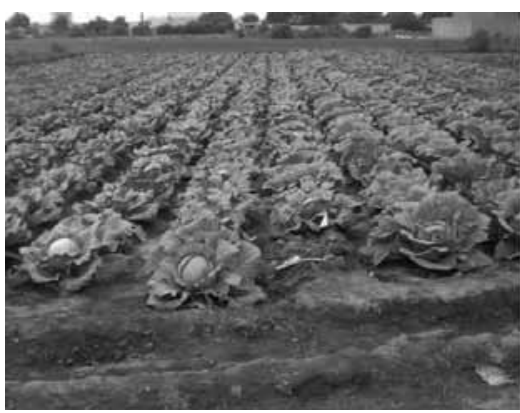

\section{Fotografía IV \\ Variedad de col introducida en Acatzingo}

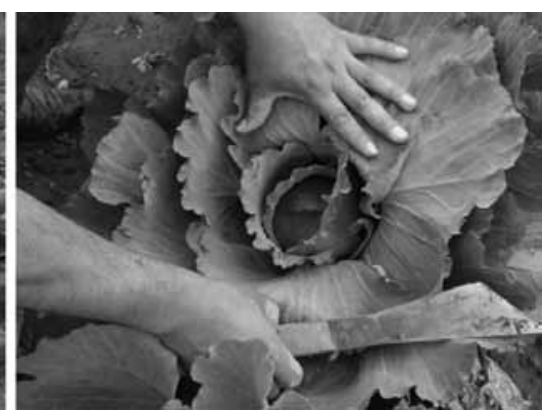

El cultivo en el municipio tiene un rendimiento de 43 toneladas por hectárea. Su precio depende de la oferta y la demanda, en Acatzingo la producción es dirigida, por una parte al mercado regional, nacional (ciudad de México) e internacional que requiere de una col con un peso promedio de 1.5 kilogramos. Por otra parte, al mercado del sureste (Veracruz, Chiapas, Tabasco, Yucatán, Quintana Roo) que requiere de coles con un peso promedio de ocho kilogramos. Para ambas coles (chica y grande) los costos de producción se ubican en los 40,000 pesos.

Los pequeños productores señalan que esta diferenciación del mercado de la col le genera ingresos netos en 15\% (figura vi), en caso de que la demanda baje, las pérdidas son totales. Esto se explica, en parte, por el tipo de demanda de la col: en la col chica la demanda es por temporada y el precio promedio es de dos pesos por kilogramo, mientras que para la col grande la demanda es todo el ańo y el precio promedio es de tres pesos por kilogramo. Por otra parte, los hábitos de consumo también permiten el establecimiento y diferenciación del mercado de la col: en el sureste su compra es fraccionada, es decir, una col se vende de manera 


\section{Figura VI}

\section{Distribución porcentual de la cadena de valor de la col}

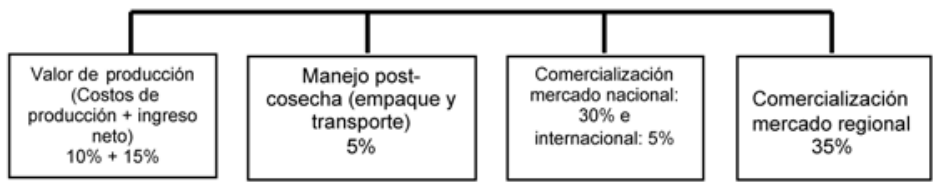

Fuente: Elaboración propia con base en los datos recopilados en campo.

seccionada según la cantidad que desee el consumidor, esto posibilita que una col de ocho kilogramos, sea vendida en ochos partes a cinco pesos la porción, vendiendo la totalidad de la col en 40 pesos. En los mercados de la col chica, el consumidor prefiere comprar la pieza completa.

El mercado de la col se distribuye de la siguiente manera: chica: $20 \%$ para venta por huerta, $30 \%$ se comercializa en la central de abasto de Huixcolotla, $45 \%$ va para el mercado de la ciudad de México y $5 \%$ se exporta. Con respecto a la col grande: $35 \%$ para venta por huerta, $65 \%$ se comercializa en la central de abasto de Huixcolotla con destino al mercado del sureste, en el cual son importantes las relaciones de subordinación debido al sistema de venta que usa la central de abasto de Huixcolotla que es una variante de la subasta holandesa.

Ejote (fruto inmaduro de Phaseolus vulgaris). Pertenece a la familia Leguminoseae, está constituido por la raíz principal, las raíces secundarias que fijan nitrógeno al suelo y el tallo, son herbáceos, delgados y la altura varía de acuerdo a la variedad, se clasifica con base en el hábito de crecimiento; las hojas son compuestas, trifoliadas, dotadas de pequeñas estipulas en la base del pecíolo; el fruto del ejote es una vaina de ancho y largo variable, encontrándose rectas o curvas con bordes redondeados o comprimidos, las semillas son arriñonadas provistas de dos cotiledones gruesos. La temperatura óptima para el desarrollo del cultivo oscila entre $10{ }^{\circ} \mathrm{C}$ a $27^{\circ} \mathrm{C}$; la textura del suelo debe ser franco arcilloso; se siembra en camas de 1.40 metros de ancho con un distanciamiento entre plantas de $0.40 \mathrm{~cm}$ y entre surcos de $0.60 \mathrm{~cm}$, en los meses de febrero a septiembre. La cosecha inicia cuando las vainitas se aproximan a su máximo tamańo pero los óvulos no han completado su desarrollo, el fruto debe ser tierno, color verde claro opaco, con un grado muy tierno de desarrollo de la semilla; el diámetro es preferible de dos a tres centímetros, y el largo de 12 a 20 centímetros.

El cultivo en el municipio tiene un rendimiento de ocho toneladas por hectárea. Su precio promedio es de seis pesos por kilogramo. Este cultivo es denominado por el pequeño productor como noble debido a que puede desarrollarse en condiciones de estrés hídrico y requiere poco 
fertilizante y plaguicida. Para este cultivo el conocimiento tradicional es de relevancia para su buen manejo agronómico. El costo de producción por hectárea no supera los 15,000 pesos y se pueden obtener ingresos netos por encima de 30 por ciento (figura VII).

\section{Figura VII}

\section{Distribución porcentual de la cadena de valor del ejote}

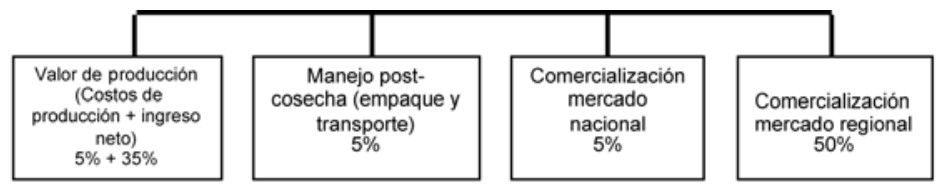

Fuente: Elaboración propia con base en los datos recopilados en campo.

Joel (29 años), habitante del municipio de Acatzingo, en octubre de 2009 comentó la experiencia de su padre con respecto a la siembra del ejote:

... el ejote depende de cómo lo quiera trabajar, mi padre, sacó recientemente un ejote de temporal, nada más lo que fue la semilla y los trabajos de la yunta esos serían los costos, estamos hablando que serían 12,000 pesos y la hectárea se la pagaron a 40,000 pesos. Pero eso fue por saberlo trabajar, aprovecho la condición climática del cielo y le dio una buena alimentación a la superficie. Mi padre antes de sembrar su ejote, sembró primero avena, la roleó y luego le sembró cebada y la volvió a rolear. No aplicó fertilizante ni riego.

El mercado del ejote es poco diversificado, se comercializa en su totalidad en la central de abasto de Huixcolotla y es controlado por siete pequeños productores que a diario venden tres toneladas. Debido a que la producción es casi controlada por un grupo de pequeńos productores han podido establecer relaciones de negociación con sus compradores con márgenes por encima de sus costos de producción.

Perejil (Petroselinum sativum). Pertenece a la familia Umbelliferae, es una planta vivaz de raíz simple, ramificada a veces, blanco-amarillento; el tallo es anguloso y ramificado; las hojas son lustrosas, de color verde oscuro; se puede cultivar, prácticamente en todo tipo de climas, si bien, los suelos humíferos son los más indicados ( $\mathrm{pH}$ neutro), se adapta a cualquier tipo de terreno, prefiere los profundos, sueltos, frescos, provistos de materia orgánica muy descompuesta. Las semillas germinan con dificultad; el fruto es un diaquenio que se emplea como semilla, de tres a cuatro mm de diámetro, ovoide, comprimido y provisto de cinco costillas; su poder germinativo suele durar dos años. Por siembra directa, se emplean de 25 a 30 kilos de semilla por hectárea, o bien en semillero. La 
germinación es muy lenta, tardando casi un mes en aparecer las plantitas, debiéndose mantener el suelo continuamente húmedo.

Este cultivo en el municipio es de reciente introducción, su proceso de adopción por parte del pequeño productor se debe a que es muy redituable (se pueden hacer hasta siete cortes al año) (figura VIII). Razón por la cual las relaciones de negociación que establecen los pequeños productores con sus compradores, en la mayoría de los casos, les favorecen con márgenes por encima de los costos de producción y en menor proporción establecen relaciones de subordinación debido al esquema de venta por huerta. Su costo de producción es de 40,000 pesos. En el primer corte se obtiene ganancia de 30,000 pesos por hectárea, en el segundo corte de 25,000 pesos, en el tercero de 20,000 pesos y del cuarto al séptimo corte 10,000 pesos. Cada corte da unos 7,000 manojos (un manojo tiene un peso de cuatro kilogramos).

\section{Figura VIII}

\section{Distribución porcentual de la cadena de valor del perejil}

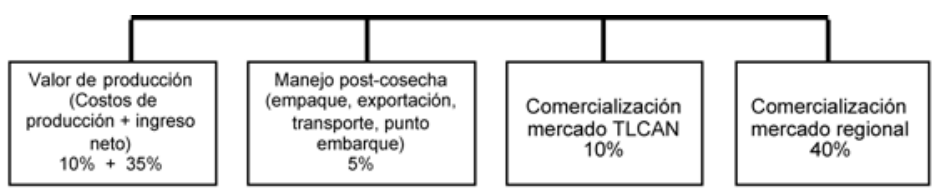

Fuente: Elaboración propia con base en los datos recopilados en campo.

El mercado del perejil en la actualidad está en formación y su distribución es la siguiente: $20 \%$ se vende por huerta y el resto se comercializa en la central de abasto de Huixcolotla. Es un producto en el que los pequeños productores de Acatzingo están apostando debido a la potencial demanda internacional, sin embargo se debe trabajar en la inocuidad del cultivo como condición básica para acceder a dichos mercados.

Poro (Allium ampeloprasum). Pertenece a la familia Liliaceae, la planta consta de tres partes bien diferenciadas: hojas largas, lanceoladas color verde oscuro y verde azulado, abiertas hacia arriba (fotografía v). El bulbo es membranoso, alargado, blanco y brillante, numerosas raíces pequeñas también de color blanco van unidas a la base del bulbo, tiene aproximadamente unos cinco centímetros de altura, y de tres a cinco centímetros de grosor, el tamaño depende de la exigencia del mercado; es más parecido a la cebolla que al ajo en su composición, con un contenido alto de agua; presentan una parte bien diferenciada entre la parte superior de la hoja y la parte basal de la misma. Puede desarrollarse en cualquier clima, aunque responde mejor en zonas de clima suave y húmedo. Puede resistir al frío, aunque otras variedades prefieren temperaturas más templadas y 


\section{Fotografía v \\ El cultivo de poro}

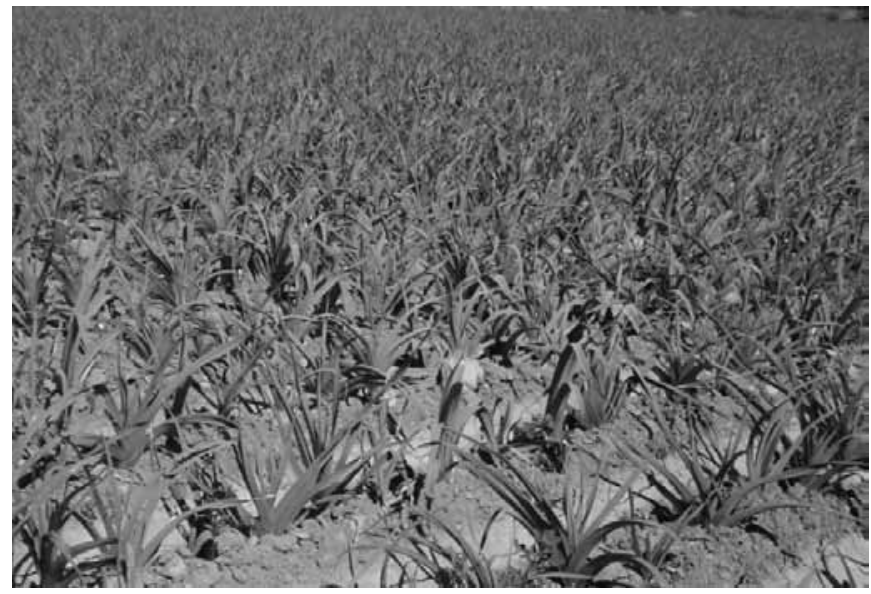

húmedas. Requiere una temperatura óptima de desarrollo vegetativo de 13 a $24^{\circ} \mathrm{C}$. Se adapta bien a suelos profundos, frescos y ricos en materia orgánica.

La siembra tiene lugar en semilleros con una cantidad aproximada de 8 a $10 \mathrm{gr} / \mathrm{m}^{2}$, produciendo unas 800 plántulas $/ \mathrm{m}^{2}$, enterrándolas o cubriéndolas posteriormente. Las plántulas se mantienen en el semillero unos dos meses, hasta alcanzar una altura aproximada de 15 a $20 \mathrm{~cm}$ para posteriormente ser trasplantadas en la zona de cultivo. Su cosecha tiene lugar aproximadamente a los cuatro meses de realizarse la siembra.

El cultivo, en el municipio, tiene un rendimiento de 10 toneladas por hectárea y su superficie de siembra no excede las 60 hectáreas. Su precio en el mercado promedia los cuatro pesos por kilogramo. Su costo de producción es de 20,000 pesos por hectárea. Su bajo costo de producción le permite al pequeño productor lograr ingresos netos de $25 \%$ (figura IX). Se comercializa por manojo (un manojo tiene un peso de tres kilogramos).

\section{Figura IX}

\section{Distribución porcentual de la cadena de valor del poro}

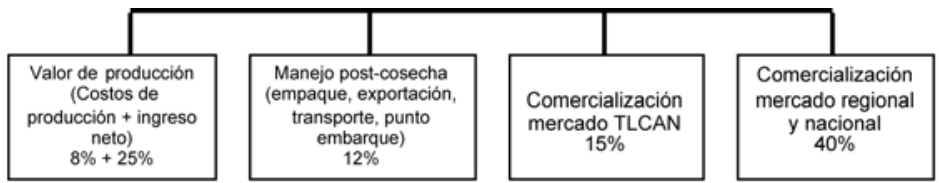

Fuente: Elaboración propia con base en los datos recopilados en campo. 
El mercado del poro le permite al pequeño productor establecer relaciones de negociación y subordinación. Las relaciones de negociación que establecen le reportan al productor, márgenes de ganancia por encima de los costos de producción, esta situación es debido a la diversificación del mercado del poro. Las relaciones de subordinación aparecen debido a dos causas: la primera se asocia al forcejeo que realizan los pequeños productores cuando venden su producto en la central de abasto de Huixcolotla, y la segunda, a la producción estacional de poro en Estados Unidos, el cual abastece el mercado interno con la consecuencia de que los productores mexicanos deben sustituir dicho mercado y en dicha transición establecen arreglos desfavorables. Pero estas condiciones del mercado estadounidense no son permanentes debido a la variabilidad climática, situación que aprovechan los pequeños productores de poro.

La producción de poro se distribuye de la siguiente manera: $50 \%$ se comercializa en la central de abasto de Huixcolotla, 30\% para el mercado de la ciudad de México, 10\% para las tiendas de autoservicio y $10 \%$ para el mercado de exportación.

Rábano (Raphanus sativus). Pertenece a la familia Umbelliferae, es una raíz gruesa, carnosa, muy variable en cuanto a la forma y tamaño, de piel roja rosada; el tallo, breve antes de la floración, con una roseta de hojas. Se desarrolla en climas templados, teniendo en cuenta que hay que proteger al cultivo durante las épocas de elevadas temperaturas. El ciclo del cultivo depende de las condiciones climáticas, pudiendo encontrar desde 20 a más de 70 días. La temperatura óptima de germinación está entre 20 y $25^{\circ} \mathrm{C}$. Se adapta a cualquier tipo de suelo, aunque prefiere los suelos profundos, arcillosos y neutros. La siembra es con semilla de asiento, se esparce al voleo a razón de $10 \mathrm{~kg}$ de semilla por hectárea en promedio. La cosecha se realiza a partir de los 45 días.

El cultivo en el municipio tiene un rendimiento de 30 toneladas por hectárea. Su precio promedio es de cuatro pesos por kilogramo. Al igual que el ejote es un cultivo noble que requiere de pocos insumos. Su costo de producción no supera los 30,000 pesos por hectárea lo que posibilita ingresos netos por encima de $15 \%$ (figura $\mathrm{x}$ ). Se comercializa por manojo (un manojo tiene un peso de 1.5 kilogramos).

\section{Figura $x$}

\section{Distribución porcentual de la cadena de valor del rábano}

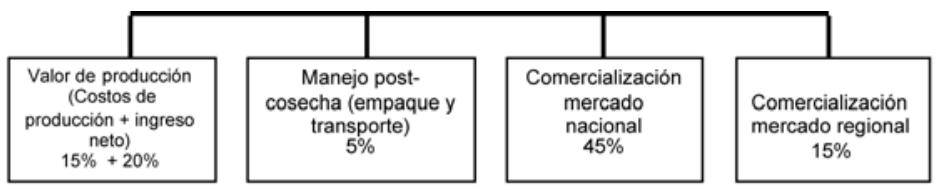

Fuente: Elaboración propia con base en los datos recopilados en campo. 
Los pequeños productores de rábano señalan que su demanda es constante durante todo el año. Su mercado es diversificado: $35 \%$ se comercializa para el mercado de la ciudad de México, $45 \%$ para el mercado del sureste, $10 \%$ se vende en la central de abasto de Huixcolotla y $10 \%$ en las tiendas de autoservicio. Para este cultivo, los pequeńos productores se están organizando para darle valor agregado y comercializarlo en los mercados cautivos, tales como el asiático (fotografía vi). Es un producto que debido a su dinámica de consumo le ofrece la oportunidad al pequeño productor de establecer relaciones de negociación favorables.

\section{Fotografía VI \\ El cultivo del rábano con valor agregado (deshidratado, en proceso de prueba)}

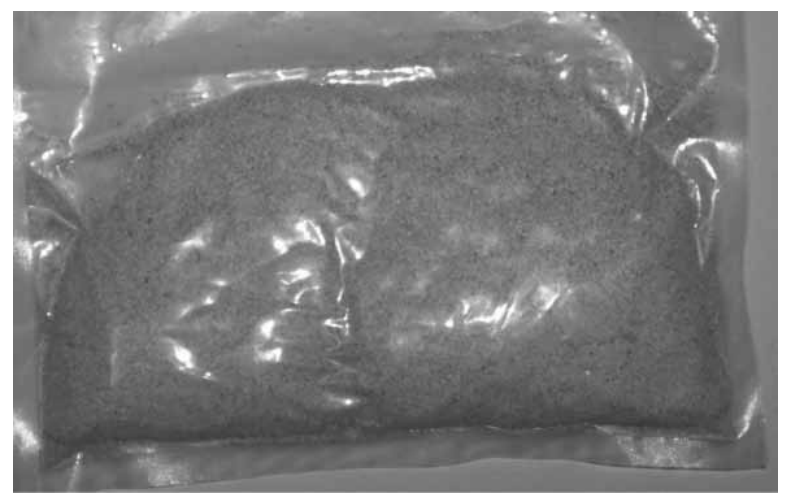

Tomate verde (Physalis ixocarpa). Pertenece a la familia Solanaceae, es una planta anual de $50 \mathrm{~cm}$ a un metro de altura, hojas alternas, largamente ovadas, tallo largo y ramas cubiertas en forma de corazón; sus flores son monopétalas, amarillentas, con manchas oscuras; el fruto es esférico de unos tres centímetros de diámetro, liso, color verdoso, algo pegajoso, cubierto por el cáliz persistente. Se desarrolla bien en casi todos los terrenos y climas, su límite lo establecen las heladas. La siembra por trasplante se realiza al aire libre en un lugar protegido de los rayos directos del sol y de los vientos, se cultiva preferentemente en tierras que disponen de riego; por ello, las fechas de siembra varían dentro de cada zona productora, lo cual explica que se encuentre en el mercado todo el año. La cosecha es preferentemente manual e inicia cuando la cáscara que los cubre se abre.

Es un cultivo de importancia para el municipio, su rendimiento es de 10 toneladas por hectárea y se le pueden dar tres cortes. Se comercializa en cajas de 15 kilogramos, en temporada de alta demanda, la caja puede llegar a costar 150 pesos, y en temporada baja su precio se ubica en 30 pesos por caja. Su costo de producción es de 30,000 pesos por hectárea, 
lo que posibilita según la demanda obtener ingresos netos entre 20 y $80 \%$ (figura XI).

Figura XI

Distribución porcentual de la cadena de valor del tomate verde

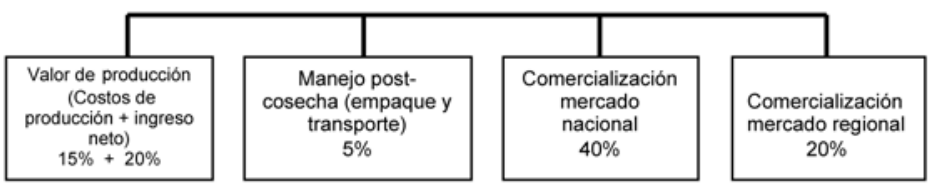

Fuente: Elaboración propia con base en los datos recopilados en campo.

El mercado del tomate verde le permite al pequeño productor establecer relaciones de negociación y subordinación. Las relaciones de negociación que establecen le reportan al productor márgenes de ganancia por encima de los costos de producción, esto debido a la diversificación del mercado del tomate. Pero cuando los arreglos se establecen en la central de abasto de Huixcolotla estos márgenes pueden reducirse hasta ser negativos, apareciendo de este modo las relaciones de subordinación.

El mercado del tomate verde se distribuye de la siguiente manera: $50 \%$ se comercializa para el mercado de la ciudad de México, 25\% se vende en la central de abasto de Huixcolotla, 20\% se comercializa para el mercado del sureste y $5 \%$ se vende a las tiendas de autoservicio. En la actualidad la exportación del tomate verde presenta obstáculos por el manejo de las plagas.

Las relaciones predominantes (negociación y subordinación) sugieren que los pequeńos productores son parte de una red social (cuadro 3), dentro de la cadena de valor hortícola para la venta de sus productos. De igual manera, constituyen el eslabón primario sujeto al poder económico de las cadenas de autoservicio, empacadoras y exportadoras, condición que les permite negociar una proporción importante de los excedentes económicos que se generan en el sistema hortícola. Por otra parte, se observa cómo el pequeño productor articula su estrategia de acuerdo al cultivo que le genera mayor rentabilidad, de esta manera establece redes que le permiten acceder a una diversidad de compradores. Esta situación pudiera generarle ventajas a la hora de establecer relaciones de negociación con las tiendas de autoservicio.

\section{Las tiendas de autoservicio y la expansión de los supermercados}

Con la dinamización de los sistemas productivos hortícolas en Puebla, muchas tiendas de autoservicio vieron la oportunidad de hacer negocios, en una primera fase a través de las empresas empacadoras. En una segun- 


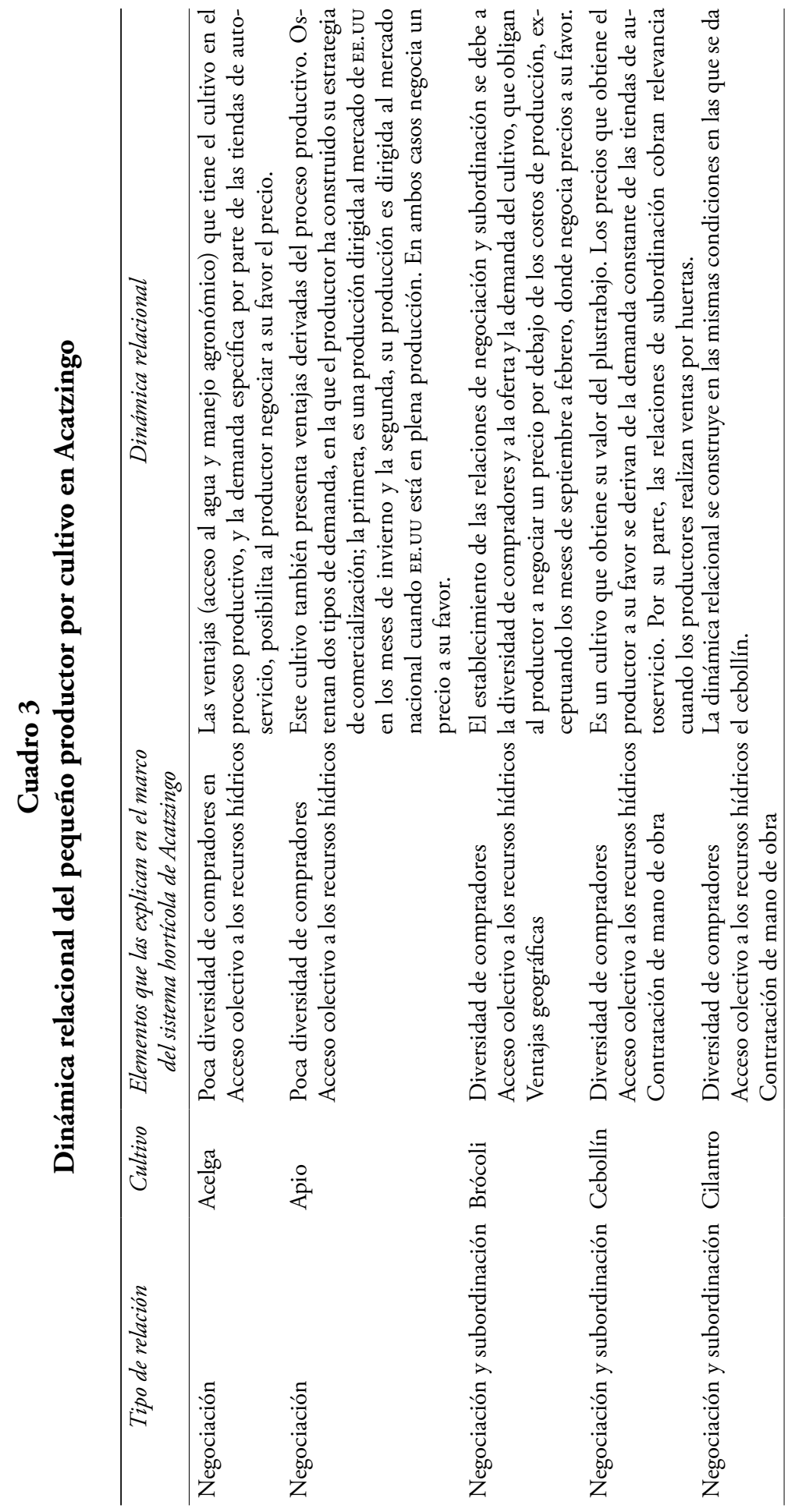




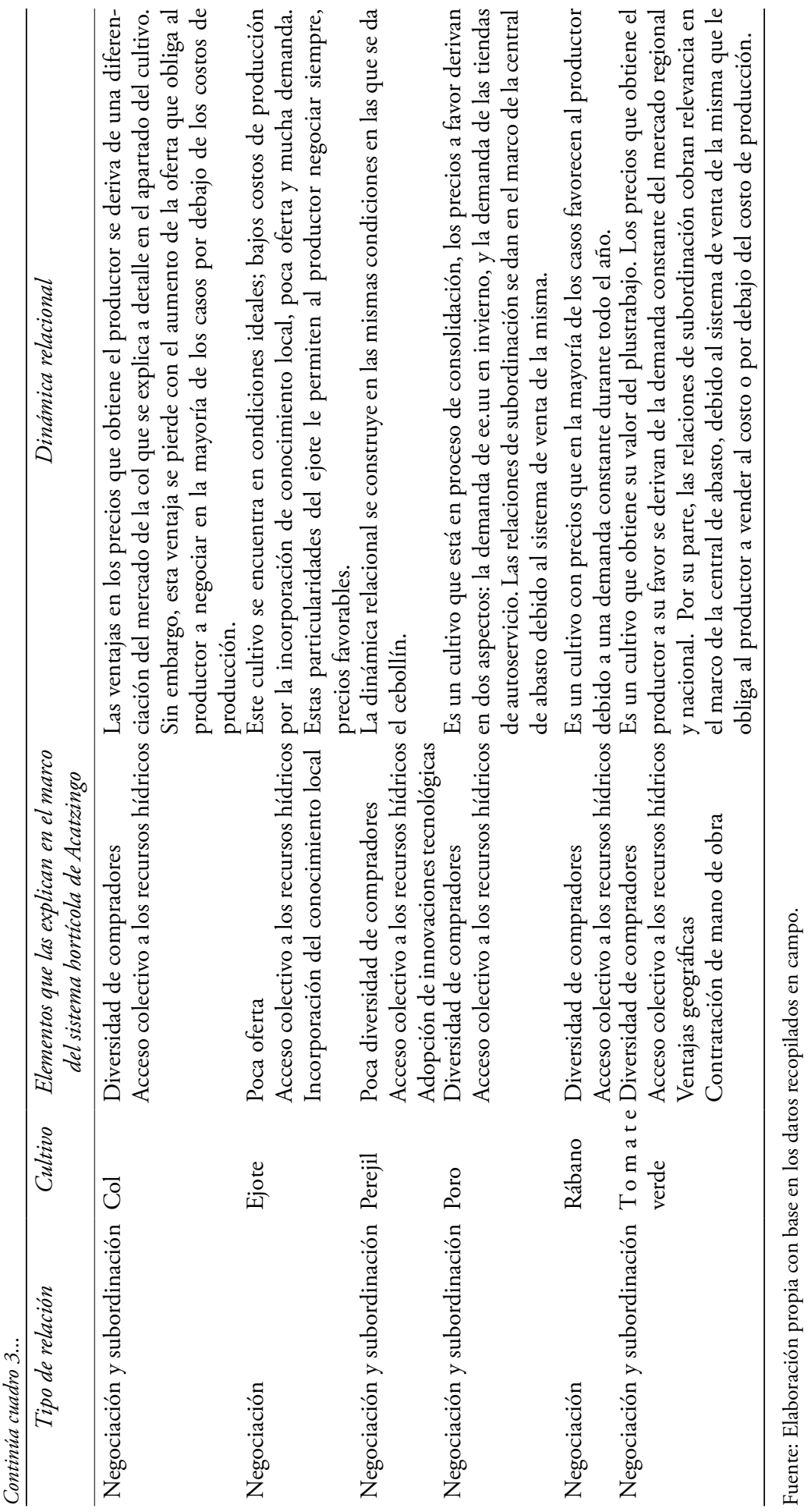


da fase, estableciendo negocios directamente con los pequeños productores. Las tiendas de autoservicio se basan en el sistema directo de ventas al consumidor y exhiben productos y artículos en forma abierta, clasificándolos por categorías y tipos, sobre todo abarrotes, perecederos, ropa y mercancías generales. Ofrecen atención a los clientes con la menor intervención del personal y un área de pago, con sistemas de punto de venta a la salida. El concepto de tienda por autoservicio incluye a los supermercados (Schwentesius y Gómez, 2006).

En México el primer supermercado abrió en 1946, pero no fue hasta los años ochenta cuando se empieza a acelerar el proceso de difusión de estas tiendas y a marcar el inicio de una segunda fase, en la cual los supermercados se expanden en cadena hacia otras ciudades grandes e incursionan en las medianas. La expansión de estas tiendas se acompaña de una fuerte competencia por absorber las cadenas pequeñas que operaban en ciudades importantes en términos económicos, tales como Guadalajara y Monterrey, que consideraron estratégicas para su futuro crecimiento (Schwentesius y Gómez, 2006).

En este contexto, se evidencia un acelerado crecimiento de los supermercados resaltando dos aspectos: el posicionamiento geográfico y las ventas que le han permitido sostener su política de expansión, (cuadro 4).

Las cadenas de autoservicio: Gigante, Comercial Mexicana y Chedraui han establecido alianzas y fusiones con la finalidad de poder competir con Soriana y Walmart, en particular con esta última que en 2009 ocupaba la cuarta posición como la empresa más rentable de México, y en el 2010 la Fundación Walmart de México fue reconocida con el premio Word Business and Development por el Programa de Desarrollo de las Naciones Unidas (UNDP), la Cámara Internacional de Comercio (ICC) y el Foro Internacional de Líderes de Negocios (IBLF). De acuerdo con Schwentesius y Gómez (2006) las empresas extranjeras entraron al mercado mexicano, hasta entonces controlado por las cadenas locales, mediante alianzas, fracturándose después de la crisis económica de 1994. Con excepción de Walmart, que logró adquirir la totalidad de la cadena Aurrera, estrategia que le ha permitido encabezar las cadenas de supermercados en México.

\section{Análisis del posicionamiento de Walmart en el sistema productivo hortícola regional}

Walmart comienza sus actividades comerciales a principios de la década de los sesenta, en adelante y debido a su éxito, incorpora restaurantes y supermercados para colonias de distintas clases sociales; entre los restaurantes se cuentan Vips y El Portón, y entre los supermercados: Walmart, Superama y Bodega Aurrera. Es una empresa norteamericana cuyo 


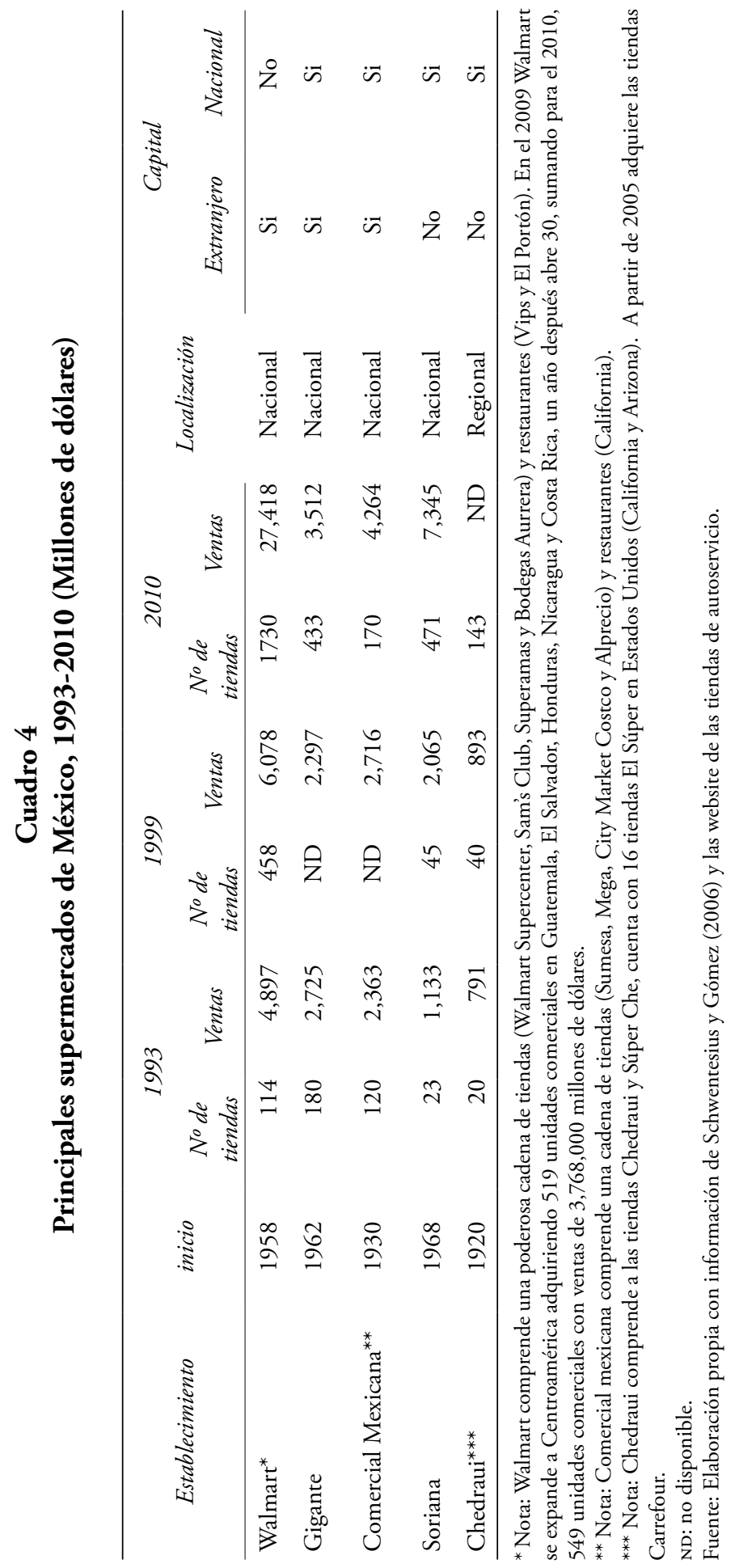


accionista mayoritario es Walmart Stores Inc., capital estadounidense y desde 1977, debido a su acelerado crecimiento en la geografía mexicana, comienza a cotizar en la Bolsa Mexicana de Valores. En 2007 crea su propio Banco para impulsar su política de crédito al consumo, estrategia que ha tenido buenos resultados ya que hasta diciembre de 2010 se han abierto 73 sucursales de Banco Walmart. Tiene presencia en más de 270 ciudades de la república mexicana con unas 1,730 unidades comerciales contabilizadas al 31 de diciembre 2010 (Walmart, 2011).

En los últimos 10 años sus ingresos han aumentado de manera importante, en 1999 superaron los seis millones de dólares. En 2009 las ventas fueron de 21,552 millones de dólares, lo que representa un incremento de más de 300 por ciento. Para el 2010 sus ventas fueron de 27,418 millones de dólares, importe que representa un incremento de $24.2 \%$ sobre las ventas obtenidas en 2009. Del total de los ingresos se estima que $12 \%$ corresponde a la venta de hortalizas frescas (Walmart, 2011; Schwentesius y Gómez, 2006).

Lo anterior, permite posicionar a esta cadena de autoservicio como la más importante de México. Esta empresa para los pequeños productores hortícolas representa una buena opción con referencia a la diversidad de compradores del sistema, Walmart mejora los precios de sus competidores (el productor obtiene 15\% de ganancia por encima de los costos de producción). Sin embargo, existen algunos aspectos que son necesarios ajustar en la lógica de la empresa y su articulación con los pequeños productores de hortalizas.

\section{Requerimiento de abastecimiento y sistema de arreglos de Walmart}

Para satisfacer las exigencias de los consumidores finales, en cuanto a calidad y frescura de los productos, y distinguirse de otros establecimientos, Walmart establece condiciones y requisitos estrictos en la adquisición de hortalizas: a) exige entrega continua en el volumen y la calidad; b) prefieren entregas en cantidades reducidas pero uniforme; c) pagan en plazos de entre 30 y 60 días; d) negocian con anterioridad productos a precios muy reducidos para presentar ofertas durante todo el año, e) los productos deben ser empacados en cajas de plástico y $\mathrm{f}$ ) reciben el producto desde las 7:00 a las 9:00 horas del día. Adicionalmente, Schwentesius y Gómez (2006) señalan que: a) toleran apenas $10 \%$ de producto dańado y b) exigen transporte con temperatura controlada.

Estos esquemas de abasto, según los pequeños productores, complican el proceso de comercialización, ya que darle valor agregado en los términos exigidos por Walmart incrementa de manera importante los costos 
para el productor. Sin contar que el esquema de pagos de Walmart precisa que los pequeños productores estén capitalizados para poder aguantar entre 30 y 60 días sin recibir el pago de su producto.

$\mathrm{Al}$ respecto César de 28 años, habitante del municipio de Acatzingo, señaló en octubre de 2009 que:

... las tiendas Walmart son bastante exigentes en términos de la calidad e higiene, hasta la temperatura, que es un gran problema para la mayoría; el productor, dadas sus condiciones, apenas puede producir con un sistema tradicional, estas exigencias complican la entrada de nuestros productos...

A nivel local Walmart establece relaciones directas con el pequeño productor y en menor proporción se abaste de las empresas empacadoras y de la central de abasto de Huixcolotla, en caso de una alta demanda de hortalizas, complementa su abasto con otras centrales (ciudad de México, Guadalajara y Monterrey), las cuales tradicionalmente han empleado para abastecerse (Schwentesius y Gómez, 2002; 2006). Walmart ha ideado un sistema de arreglos que le garantiza un abasto continuo, este sistema inicia con los actores de las centrales de abasto y proveedores con quienes hace negocios, mismos con los que ha construido una compleja red de información. Para explicar como funciona esta red tomaremos como ejemplo, la Asociación de Productores y Empacadores Exportadores de Aguacate de Michoacán (APEAM) (organización que cuenta con más de 5,000 productores, 29 empacadoras con registro de exportación a Estados Unidos, abastece $50 \%$ de los aguacates que se consumen y poseen 50,000 hectáreas en producción con un valor de anual de 500 millones de dólares), esta organización para mantenerse informada con referencia a los precios, contrata agentes en todas las centrales de México y Estados Unidos que reportan a diario las variaciones de precio que tuvo el producto, a estos agentes se les denomina visores o monitores, de esta manera tienen suficientes elementos para negociar el precio final del producto. Adicionalmente, Walmart realiza acuerdos con bodegueros, empacadores y comerciantes, que le garantizan el abasto de productos de calidad en situaciones no previstas. El siguiente testimonio de Lorenzo de 66 ańos, habitante de Huixcolotla y asesor de la central de abasto de ese municipio, en 2008 comentó:

Las grandes tiendas de autoservicio (Walmart, Soriana, Chedraui) le compran a las centrales de abasto un método que han ideado para sacar información, es la convocatoria a congresos para intercambiar experiencias, en estos congresos corre el vino y las mujeres, y le han sacado la sopa (información) a los bodegueros de México (dónde compras, a quién le compras, cómo pagas), de esta manera Walmart ya conoce los movimientos de la mayoría de los bodegueros de las centrales de abasto. 
Por otra parte, a nivel local Walmart influye en los niveles de participación de intermediarios, reformulando sus estrategias de compra-venta a través de arreglos engañosos directamente con el pequeño productor, haciéndole ver que obtienen ganancia por encima de 15\%; sin embargo no es así, ya que el producto lo adquiere más barato, de tal forma que el productor percibe entre 10 y $15 \%$ de ganancia por sus productos, y los costos por la supresión de un eslabón de la cadena (intermediario) son absorbidos por la empresa, convirtiéndose en ganancia.

Otra forma de arreglo es a través de la legitimación social y el prestigio que tiene la empresa que le ha servido para ser un gran centro de acopio a nivel nacional, la empresa no posee empleados buscando potenciales vendedores de hortalizas, son los propios productores quienes se acercan a negociar sus productos transfiriendo información sensible de precios, calidad, zonas productoras y calendarización de cosechas. De esta forma es como compradores especializados por grupo de cultivos (hortalizas, frutas, tubérculos, etc.,) de la empresa, desde la comodidad de su oficina, manejan una gran cantidad de información de la región, aspecto que le permite negociar un precio a su favor, en casos de arreglos con poco margen de maniobra, el representante de Walmart negocia a un precio muy reducido con otro producto hortícola, con varios meses de antelación. Este tipo de arreglo, en particular, le va permitir controlar el precio de dicha hortaliza; el siguiente testimonio obtenido en octubre de 2009, correspondiente a César de 28 años, habitante de Acatzingo, aunque no es referido directamente a un cultivo hortícola, da cuenta de lo señalado:

\footnotetext{
... Conocí una persona que tenía bastante papa y se la fue a vender a Walmart a buen precio, el comprador de Walmart intentó negociar a la baja, pero el precio propuesto por el productor de papa fue defendido. Su argumento era que sabía que casi toda la papa de esa temporada él la había producido y no tenía competencia. El de Walmart, finalmente accedió y dijo: "ok no hay papa, entonces te la voy comprar toda, siempre y cuando hagamos un convenio: que para diciembre vas a sembrar betabel y el betabel me lo vas a dar casi regalado a un precio de miseria”... el productor le dijo: está bien aceptó, tú ganas, y yo gano.
}

Esta estrategia de comercialización de Walmart permite capitalizar al pequeño productor, a la vez que puede ofrecer productos hortícolas de calidad a muy bajos precios. La estrategia de Walmart, descrita anteriormente, le permite vender el resto de sus productos hortícolas a precios altos, establecidos por ellos. Las implicaciones que tiene esta estrategia para el resto de los pequeños productores de betabel, en el caso del testimonio, son negativas, ya que se encuentran un mercado con un precio por el suelo, desconociendo que la conformación del precio fue controlada. 


\section{Conclusiones}

Walmart es la principal tienda de autoservicio a nivel regional y nacional, su expansión geográfica así como sus ventas son elementos relevantes que evidencian lo señalado. Su posicionamiento a nivel local es debido básicamente a las negociaciones que realiza de manera directa con los pequeños productores del municipio, minimizando la participación de intermediarios. En un ámbito más amplio mantiene una red de monitores a nivel nacional que le permite tener acceso diariamente a los precios. Además, de mantener acuerdos con bodegueros, empacadores y comerciantes que le proporcionan información sobre calidad del producto, zonas productoras y calendarización de cosechas.

De esta manera, Walmart ha desarrollado a lo largo de su permanencia en los territorios rurales mexicanos un manejo eficaz de la información sensible relacionada con las hortalizas, en particular, ha podido identificar cuellos de botella que tiene el sistema hortícola en la región (falta de organización, proceso de post-cosecha no maquilados, poco acceso a la información de mercados y la falta de financiamiento) que mientras no se superen, el pequeño productor hortícola de Acatzingo sólo producirá para sobrevivir él y su entorno familiar.

Es importante mencionar que debido al modelo de desarrollo actual que ostenta México, su población demanda cada vez más hortalizas en calidad y cantidad; lo anterior, ha llevado a Walmart a trasladar dichas exigencias a sus proveedores, en particular, a los pequeños productores, que enfrentan dificultades para atender tales demandas, ya que no cuentan con financiamiento. En el municipio las exigencias de importancia para los pequeños productores son: a) transporte con temperatura controlada; b) entrega continua en el volumen y la calidad; c) forma de pago, y d) manejo post-cosecha de los productos hortícolas. Sin embargo, a pesar de las exigencias previamente mencionadas, los pequeńos productores han desplegado estrategias que le han permitido transitar y manejar sus relaciones comerciales con Walmart.

En este sentido, los resultados del estudio indican que en Acatzingo, los pequeños productores han establecido redes sociales tanto reactivas (surgen ante la necesidad de responder a problemas ya existentes), como proactivas (intentan descubrir nuevas oportunidades), que le han permitido diversificar la comercialización de sus productos, esta estrategia de los pequeños productores locales genera una forma de capitalizarse y de innovar. Otra estrategia es la construcción de espacios intersticios que se evidencian en las relaciones de negociación y subordinación y en su lógica racional, es decir, tienen cierta autonomía que le permite decidir qué, cuándo, cómo y cuánto producir. La diversidad de hortalizas que cultivan, 
relacionadas comercialmente con Walmart se pueden constatar en el cuadro 2. Por otra parte, han avanzado a nivel organizativo, la acción colectiva en el marco de los recursos económicos e hídricos es una muestra de ello.

Finalmente, el análisis apunta hacia la hegemonía de Walmart dentro del grupo de las empresas comerciales o tiendas de autoservicio a nivel regional, este liderazgo le permite controlar e imponer precios en todo el sistema hortícola regional, y sus relaciones con los pequeños productores hortícolas se pueden entender en términos de arreglos, intereses y necesidades económicas, tanto en la esfera colectiva como individual.

\section{Bibliografía}

Borbón, Carlos (2001), "Frutas y hortalizas de exportación: una aproximación al enfoque de las cadenas comerciales globales", Región y Sociedad, xIII (22), El Colegio de Sonora, Sonora, pp. 161-174.

Browne, Kath (2005), "Snowball sampling: using social networks to research non-heterosexual women", International Journal of Social Research, 8 (1), Ordu, pp. 47-60.

FIU (Florida International University) (2006), "El mercado de Estados Unidos para el apio”, Mimeo, Maestría en Marketing Strategy, Florida.

Holdridge, Leslie (1978), Ecología en zonas de vida, Organización de Estados Americanos (OEA)-Instituto Interamericano de Ciencias Agrícolas, San José de Costa Rica.

Lugo-Morin, Diosey Ramón (2010a), "La acción colectiva rural y dinámica reticular de los actores sociales en el altiplano poblano. Un estudio de caso", Tesis doctoral, Colegio de Postgraduados, Puebla.

Lugo-Morin, Diosey Ramón, Javier Ramírez Juárez, José Arturo Méndez Espinoza y Benjamín, Peña Olvera (2010b), "Redes sociales asimétricas en el sistema hortícola del valle de Tepeaca”, Economía, Sociedad y Territorio, vol. x, núm. 32, El Colegio Mexiquense, Zinacantepec, pp. 207-230.

OEIDRus (Oficina Estatal de Información para el Desarrollo Rural Sustentable) (2009), Anuario estadístico de la producción agrícola 2001-2007, <http://www.oeidrus-puebla.gob.mx/>, 26 de agosto de 2009. 
Rappo, Susana y Rosalía Vázquez (2006), La construcción del desarrollo sustentable en la región centro-oriente de Puebla, Benemérita Universidad Autónoma de Puebla, Puebla.

Reardon, Thomas y Julio Berdegué (2002), “The rapid rise of supermarkets in Latin America: challenges and opportunities for development", Development Policy Review, 20 (4), Overseas Development Institute, London, pp. 371-388.

Sagarpa (Secretaría de Agricultura, Ganadería, Desarrollo Rural, Pesca y Alimentación) (2008), Anuario estadistico de la producción agricola por municipio, México, http://www.siap.gob.mx, 28 agosto de 2009.

Santesmases, Miguel (2001), DYANE. Diseño y análisis de encuestas en investigación social y de mercados, Pirámide, Madrid.

Schwentesius, Rita y Manuel Ángel Gómez (1997), “Competitividad de la producción hortícola mexicana en el mercado norteamericano, Tendencias a tres años del TLC", ponencia presentada en el xx International Congress of the Latin American Studies Association, 17-19 de abril, Guadalajara, pp. 1-25.

Schwentesius, Rita y Manuel Ángel Gómez (2002), "Supermarkets in Mexico: impacts on horticulture systems", Development Policy Review, 20 (4), Overseas Development Institute, London, pp. 487-502.

Schwentesius, Rita y Manuel Ángel Gómez (2006), “Supermercados y pequeños productores hortofrutícolas en México", Comercio Exterior, 56 (3), México, pp. 205-218.

Snijders, Tom (1992), "Estimation on the basis of snowball samples: how to weight", Bulletin de Méthodologie Sociologique, 36, París, pp. 59-70.

Walmart (2011), Reporte de ventas mensuales para inversionistas 2010, Walmart, México D.F. <http://www.walmartmexico.com.mx>, 27 enero de 2011. 
Recibido: 24 de abril de 2011.

Reenviado: 27 de julio de 2011. Reenviado: 28 de agosto de 2011. Aceptado: 19 de septiembre de 2011.

Diosey Ramón Lugo-Morin. Es doctor en ciencias en estrategias para el desarrollo agrícola regional por el Colegio de Postgraduados (Colpos), México. Actualmente es consultor y profesor en el Programa de Doctorado en Sostenibilidad en la Universidad Europea de Energía y Medio Ambiente. Su línea de investigación actual es el desarrollo rural sustentable. Entre sus publicaciones más recientes se encuentran: "El espacio rural portugués en el marco de la política agrícola común europea: algunas implicaciones para la agricultura familiar", Economia, Sociedad y Territorio, vol. xII, núm. 39, El Colegio Mexiquense, Zinacantepec, pp. 473-492 (2012); “¿Cómo un problema ambiental se transforma en una posibilidad económica para las comunidades rurales", Ciencia y Sociedad, vol. 37, num. 1, INTEC, Santo Domingo, República Dominicana, pp. 122-139 (2012). 